\title{
Jacqueline Bhabha, Andrzej Mirga, and Margareta Matache, eds. 2017. Realizing Roma Rights. Philadelphia, PA: University of Pennsylvania Press
}

\section{Book review by}

\section{Elisabetta Di Giovanni}

elisabetta.digiovanni@unipa.it

Associate Professor of Anthropology, University of Palermo

ORCID: https://orcid.org/0000-0003-0585-6804

Elisabetta Di Giovanni teaches social anthropology and ethnohistory. Her main research topics are migration issues and Roma studies, with special reference to child protection (learning courses and training workshops conducted with UNICEF on child participation for the development of human rights). She is the convenor of the University of Palermo Summer School on "Migrants, Human Rights, and Democracy," which aims to focus on forced migration, human mobilities, and welcoming refugees.

\section{Critical}

Romani Studies 
This book represents the last significant in-depth work, both theoretical and ethnographical, to reflect on Roma rights from a polyhedric perspective. It consists of a far-reaching, intense, and complete investigation on Roma issues, presenting contemporary case studies from several geographical areas (especially the United States and Europe).

Based on a critical perspective, the volume offers accurate and qualitative detailed case studies of Roma policy, aiming to increase familiarity with challenges to Roma rights and thus encouraging activists and experts who have undertaken successful strategies against social exclusion to contribute to the advancement of Roma issues. To do so, the book has been structured by its editors into five parts (1. The Long Shadow of Anti-Roma Discrimination; 2. The Longue Durée: The History of Roma as an Element in US Foreign Policy; 3. Taking Stock of European Public Policy: The Impact of Roma Inclusion Strategies; 4. The Enduring Challenge of Tackling Anti-Roma Institutional Discrimination and Popular Racism in Contemporary Europe: A Comparative Analysis; and 5. Looking Forward: The Imperative of Roma Community Mobilization and Leadership). In order to explore the dynamics of social rejection and stigma, the book collects contributions from various authors, addressing specific issues: the educational exclusion of Romani children in Italy; the reproductive rights of Romani women; practices and policies in Europe and in the USA, with an interesting focus on the challenges implemented and attempted in the last quarter of a century; institutional discrimination; mobilization; and participatory practices.

Jacqueline Bhabha's introduction, recognizing anti-Roma sentiments which still exist today, underlines the goal of several chapters, which aim to "illustrate the process whereby Roma communities are denied real access to mainstream institutions and instead forced to carve out precarious living arrangements for themselves" (11). The persistent negative representation and stereotype of Roma as nomads, unable to integrate with other people (the gage, i.e. non-Romani world), and existing as a hegemonic group, feeds a discrimination that exists on multiple levels and which destroys any potential to create a real multicultural and intercultural society. In this perspective, Elena Rozzi's chapter on the persistent educational exclusion of Romani children in Italy offers a significant analysis about the so-called "nomad" children in and outside Italian schools. Rozzi argues that low school participation among the Roma in Italy is "the result of institutional policies that segregate and marginalize this minority in society at large and in schools" (20-1). The system of labelling "nomad camps" is, as is well-known, an expensive and exclusive strategy of control that is determined to create obstacles for Romani children to keep them from obtaining their right to education. The chapter highlights that the Romani population's supposed lack of inclination towards integration and school community is a pervasive and long-term form of discrimination by the majority society; in other words, Romani students lower their performance at school as a consequence of internalizing and adapting the stereotype. Rozzi looks to the studies on school performance of minorities completed by anthropologist John Ogbu, according to whom divergence in achievement cannot be attributed entirely to cultural and linguistic differences. Using Ogbu's studies as a starting point, Rozzi outlines how in Italy the peculiar policy of "nomad camps" should be stopped immediately and, in order to pass from analysis to action, a concrete inclusive policy should prioritize support to Romani youth in their search for employment after they have finished secondary school or vocational training. 
In my opinion, chapter 1 (which is linked to chapter 11) is particularly enlightening, with its discussion of the idea that civic society has to support the concept of Roma as "responsible and active subjects" (38). In fact, the dynamic related to a concrete process of Romani empowerment is extremely interesting, and has also been explored by those in the social sciences, especially psychology, anthropology, and sociology. Specifically, Peter Vermeersch's chapter reflects on Roma activism and political mobilization in Europe, noting that these communities do not actually have the necessary organizational capacity, financial means, and symbolic resources to bring about a significant change. New social mobility strategies and new forms of youth activism must be brought about by young Roma in order to achieve a process of desegregation and real inclusion. Although a growing number of Roma are involved in various forms of political and social activism, having also increasingly been part of a transnational advocacy network on Roma inclusion, the archetype persists that Roma are politically more passive than other groups of citizens.

Vermeersch underlines that "new research is needed on the ways activists can successfully address problems in the field of Roma participation and mobilization," acquiring a significant presence in policy-making debates and influencing policy outcomes (201). After mapping the development of institutional change and emerging political opportunities in Europe since the early 1990s, giving Romani people official recognition as an ethnic group or a national minority for the first time, Vermeersch's chapter engages its readership with a fundamental question: why, despite these measures, does ethnic electoral representation of Roma remain low, both in ethnic parties and in mainstream political parties? Vermeersch shows how, while the number of Romani activists is high, the effect of Romani political activism actually remains limited. First of all, Romani communities across Europe have an unavoidable high dependence on international donors; very often other political actors (political parties, for instance) do not hold Romani participation and mobilization as a high priority, even if they are seemingly more positive about Roma. As comparative political research demonstrates, resources are a key factor; the fundamental issue is that "without the necessary organizational capacity, financial means, and symbolic resources ... Romani mobilization and participation are likely to remain unsuccessful" (207-8). Secondly, the persistent representation of Roma in the media as passive objects of policy is not an improvement. What arises from this interesting chapter is the "promising avenue" of youth engagement in activism; in fact, through inclusive education and inclusive youth activism, Roma can more easily access a variety of identities as a result of a new form of social mobilization: not only "Roma" but also "youth," becoming part of all kinds of networks and promoting new images of Romani identity.

Finally, Realizing Roma Rights represents an outstanding scientific work, and an important milestone, with a strong cohesion among the contributions to the volume, encouraging reflection on historical and contemporary Romani marginalization. 